\title{
HPV detection in stained cytological cervical specimens and correlation with cytology and histology
}

\author{
M. KOFFA ${ }^{1,2}$, H. SIMIAKAKI ${ }^{3}$, M. ERGAZAKI ${ }^{1,2}$, M. PAPAEFTHIMIOU $^{3}$, K. KARAKATSANI $^{1}$, \\ E. DIAKOMANOLIS ${ }^{4}$ and D.A. SPANDIDOS ${ }^{1,2}$ \\ ${ }^{1}$ Institute of Biological Research and Biotechnology, National Hellenic Research Foundation, Athens; \\ ${ }^{2}$ Laboratory of Virology, Medical School, University of Crete, Heraklion; ${ }^{3}$ Department of Clinical Cytology, \\ 'Alexandra' Hospital, Athens; ${ }^{4}$ Department of Colposcopy, 'Alexandra' Hospital, Athens, Greece
}

Received August 14, 1995; Accepted September 4, 1995

\begin{abstract}
It has been suggested that detection of high risk human papillomavirus (HPV) in low grade cervical intraepithelial neoplasia contributes to transition to high grade lesions and cancer. Currently, the PAP smear is the primary screening tool to identify women with cervical disease, specifically cervical intraepithelial neoplasia (CIN). In the present study we examined the utility of HPV detection and typing by PCR, in women with cytological and/or histological evidence of low grade squamous lesion (LGSL), using stained PAP cervical smears. HPV infection was confirmed in 21 out of the $31(68 \%)$ specimens examined.
\end{abstract}

\section{Introduction}

The significant role of human papillomavirus (HPV) in cervical and anogenital neoplasia is well known (1-3). HPV types 16, $18,31,33$ and 35 have been detected in association with up to $80 \%$ of high grade lesions (CIN II and III) and with up to $90 \%$ of invasive cervical cancers $(4,5)$. These types are also found in low grade lesions (CIN I and wart virus change only) and even in women with negative cervical biopsies $(6,7)$. The detection of these viral types in an individual patient might be predictive of the progression to a highergrade lesion $(8,9)$.

The management of patients with persistent borderline or wart virus change, or mild dyskaryosis is not clear as there is no cytopathological criterion to distinguish between patients who will have a low- or high-grade lesion on subsequent biopsy $(10,11)$. Moreover, about $50 \%$ of lesions diagnosed as CIN I will regress spontaneously, and a too early intervention may result in the unnecessary treatment of women who are at little or no risk of developing carcinoma. There are however, patients with CIN I in whom the disease will persist or progress to carcinoma. HPV testing may usefully augment cytology by

Correspondence to: Professor D.A. Spandidos, National Hellenic Research Foundation, 48 Vas. Constantinou Ave., Athens 11635 , Greece

Key words: human papillomavirus (HPV), cytological specimens, low grade squamous lesions (LGSL), polymerase chain reaction (PCR) helping to decide whether a patient with a mild abnormality needs immediate referral for colposcopy (9) providing a quality assurance in cervical cytopathology (12).

Although the detection of HPV infections using colposcopy, histology and cytology has been claimed, these techniques are not able to identify the virus itself, but detect the (sub-) clinical manifestation of the HPV infection (13). Moreover, the formation of koilocytes, the main cytological and histological criterion for HPV infection, and HPV-specific colposcopic pattern, can also be caused by agents other than HPV, while koilocytes can be absent in HPV infections (14). Thus the sensitivity and specificity of each of these techniques in HPV detection are rather low and controversial (15). Furthermore, they fail to discriminate between the different types of HPV (16).

With the use of the polymerase chain reaction (PCR) technique, viral DNA has been detected in cervical smears from women with no history of cervical lesions attending routine screening clinics and in substantial proportions of women with CIN or cervical carcinomas (17-20). PCR is known to be more sensitive than in situ hybridization, Southern blotting, or filter hybridization in the dectetion of HPV DNA $(21,22)$. The PCR technique is thought to increase the sensitivity of HPV DNA screening tests and give a more accurate frequency of infections as well as better estimate of disease progression.

In the present study we evaluated the potential contribution of HPV analysis in the prediction of low-grade CIN progression, as well as the correlation between HPV detection and typing by PCR with cytological and histological diagnosis. 31 stained cytological specimens from PAP smears with a cytological and/or histological diagnosis of low grade squamous lesion (LGSL) were examined and 21 were found positive for HPV DNA.

\section{Materials and methods}

Patients and specimens. Specimens were obtained from 50 women with cytological and/or histological evidence of low grade squamous lesions (LGSL: HPV and/or CIN I), treated at the Department of Cytology, 'Alexandra' Hospital, Athens, Greece. The cervical smears used were already fixed and stained to obtain the cytological diagnosis. 
DNA extraction. For each case, one slide with stained cervical smear was used. The slides were soaked for $48 \mathrm{~h}$ in xylene followed by ethanol wash, to remove the coverslip. The cells were then scraped into a $1.5 \mathrm{ml}$ Eppendorf, with the addition of $400 \mu \mathrm{l}$ digestion buffer containing $100 \mathrm{mM} \mathrm{NaCl}, 10 \mathrm{mM}$ Tris- $\mathrm{HCl}, 25 \mathrm{mM}$ EDTA, $0.5 \%$ SDS pH 8.0 and lysed with the addition of $0.1 \mathrm{mg} / \mathrm{ml}$ proteinase K (Sigma, St. Louis, MO). Samples were incubated for $24 \mathrm{~h}$ at $37^{\circ} \mathrm{C}$. Fresh proteinase K was added and the incubation was continued for another $24 \mathrm{~h}$. The samples were then extracted once with phenol/chloroform and once with chloroform. DNA was precipitated with the addition of $20 \mu \mathrm{l} 5 \mathrm{M} \mathrm{NaCl}$ and $1 \mathrm{ml}$ ethanol, recovered with centrifugation at $13000 \mathrm{rpm}$ for $15 \mathrm{~min}$ at $4^{\circ} \mathrm{C}$, washed once with cold $70 \%$ ethanol and resuspended in $20 \mu$ l double distilled water.

Oligonucleotide primers and PCR amplification. All specimens were examined for the presence of amplifiable DNA using a set of primers for a fragment of $\beta$-globin gene (23). For the distinction of HPV types a multiplex PCR was employed, using simultaneously four pairs of primers (for HPV types 11, 16, 18 and 33), with each virus type giving different length of amplified DNA (24). Two $\mu$ l of the extracted DNA of each sample was amplified in a reaction solution of $50 \mu \mathrm{l}$ containing $20 \mathrm{mM}\left(\mathrm{NH}_{4}\right)_{2} \mathrm{SO}_{4}, 2.5 \mathrm{mM} \mathrm{MgCl}, 75 \mathrm{mM}$ Tris- $\mathrm{HCl} \mathrm{pH} 9.0$, $0.01 \%(w / v)$ Tween, $200 \mu \mathrm{M}$ of each dNTP, $0.5 \mu \mathrm{M}$ of each primer and $1.25 \mathrm{U}$ Taq polymerase (Advanced Biotechnologies). The mixture was heated for $1 \mathrm{~min}$ at $95^{\circ} \mathrm{C}$, and then subjected to 35 cycles of amplification.

B-globin: Each cycle included a denaturation step at $94^{\circ} \mathrm{C}$ for $50 \mathrm{sec}$, an annealing step at $56^{\circ} \mathrm{C}$ for $40 \mathrm{sec}$ and an elongation step at $72^{\circ} \mathrm{C}$ for $40 \mathrm{sec}$, increasing the elongation time $1 \mathrm{sec}$ per cycle.

HPV: Each cycle included a denaturation step at $94^{\circ} \mathrm{C}$ for $50 \mathrm{sec}$, an annealing step at $56^{\circ} \mathrm{C}$ for $50 \mathrm{sec}$ and an elongation step at $72^{\circ} \mathrm{C}$ for $50 \mathrm{sec}$, increasing the elongation time $1 \mathrm{sec}$ per cycle. To establish type specificity of primer-directed amplification, each set of primers was tested with template plasmid DNA of the five HPV types $6 \mathrm{~b}, 11,16,18$ and 33 . PCR products were analyzed on a $2 \%$ agarose gel and photographed on a UV light transilluminator.

\section{Results}

The presence of amplifiable DNA, using primers for a fragment of $\beta$-globin gene, was confirmed in 31 out of the 50 stained smears examined. The remaining 19 cytological preparations either contained only very small number of cells, too few to be successfully scraped off the slide, or chemicals used for the fixation and staining for cytology remained after extraction, inhibiting the PCR reaction.

Detection and typing of HPV DNA was performed in the 31 specimens with a cytological and/or histological diagnosis of low grade squamous lesion (LGSL). In 21 (68\%) cases the presence of HPV DNA was confirmed, while 10 cases were found negative for HPV DNA.

The typing of the virus revealed the higher prevalence of HPV 16, found in 11 cases (36\%). HPV 11 was found in 4 cases (13\%), HPV18 in 3 cases $(10 \%)$, HPV33 in 1 case $(3.2 \%)$, while in 2 cases $(6.5 \%)$ HPV 16 and HPV11 were simultaneously detected (Fig. 1). The primers used for the multiplex

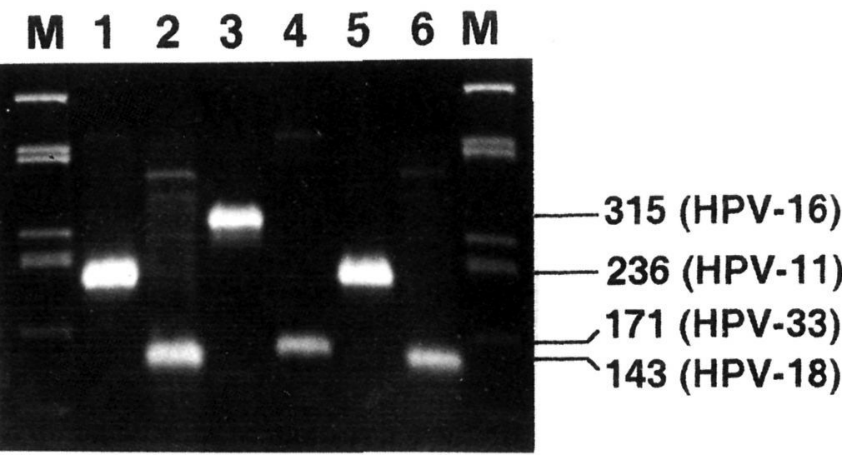

Figure 1. Detection and typing of HPV DNA using specific set of primers for each type in a multiplex PCR. The PCR products (315 bp for HPV-16, 236 bp for HPV-11, 171 bp for HPV-33 and 143 bp for HPV-18) were electrophoresed on a $2 \%$ agarose gel. Lanes $\mathrm{M}$ : Weight molecular marker pUC18/HaeIII, lanes 1,5: samples positive for HPV-11; lanes 2,6: samples positive for HPV-18; lane 3: sample positive for HPV-16; lane 4: sample positive for HPV-33.

PCR were within the E6 gene, providing amplification whether the HPV genome was episomal or integrated. Moreover, the length of the PCR products (315-143 bp) was relatively short and could be amplified from the very small yields of lowmolecular-weight DNA produced from such preparations.

After 3 years of follow-up, persistence of the disease was found in 4 cases (13\%) with high-risk HPV: 2 cases with HPV-16 (6.5\%) and two cases (6.5\%) with HPV-18. Progression of the disease was found in only one case with HPV-11 (3.2\%), in which no histological diagnosis was available. In 26 cases (84\%) (9 cases with HPV $-16,3$ cases with HPV-11, 2 cases with both HPV-16 and HPV-11, one case with HPV-18, one case with HPV-33 and 10 cases with no detectable HPV DNA of the above types) with a negative cytological diagnosis, regression of the disease was detected (Table I, Fig. 2).

\section{Discussion}

It has been suggested that HPV testing may usefully augment cytology by helping to decide whether a patient with a mild abnormality needs immediate referral (25), while testing for high-risk HPV types appears to have more clinical utility (12). The sensitivity of the PCR method provides a more accurate frequency of infections.

Formalin-fixed paraffin-embedded tissues, fresh tissues and exfoliated cervical cells recovered from cervical scrapes have been used for HPV DNA detection by PCR (26-28). However, fixed and stained cervical smears already used for cytology, which provide the possibility of retrospective studies with follow-up of the patients as well, have never been used. It is also possible to compare the results of the PCR analysis to cytology within the same sample, while confirmation as well as typing of the virus can provide further support for the treatment selection. Moreover, the ability to use archival cervical smears provides material for the investigation of cervical neoplasia and has important implications even in forensic medicine. The only disadvantage of this technique is that it obviously destroys the cytology specimen. 
Table I. HPV typing in stained cervical smears with low grade CIN and status of the disease after a 3-year follow-up of the patients.

\begin{tabular}{|c|c|c|c|c|}
\hline HPV type & No of patients & Regression & Persistence & Progression \\
\hline HPV-16 & 11 & 9 & 2 & 0 \\
\hline HPV-11 & 4 & 3 & 0 & 1 \\
\hline HPV-18 & 3 & 1 & 2 & 0 \\
\hline HPV-33 & 1 & 1 & 0 & 0 \\
\hline HPV-16+HPV-11 & 2 & 2 & 0 & 0 \\
\hline None of the above & 10 & 10 & 0 & 0 \\
\hline Total & 31 & $26(84 \%)$ & $4(13 \%)$ & $1(6.5 \%)$ \\
\hline
\end{tabular}

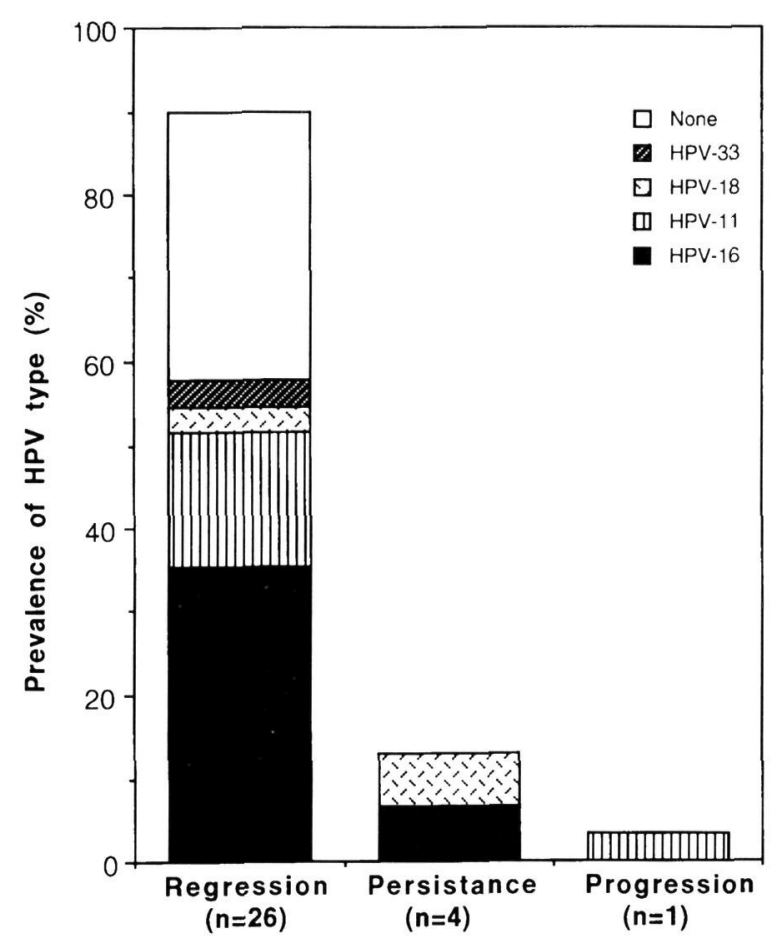

Figure 2. Disease status according to the HPV type. (Observations after 3 years of follow-up).

Due to the high sensitivity of the PCR technique, relatively low amounts of target DNA are required, which is important in the case of stained cytological material as used in this study. Moreover, the employment of the 'hot start' PCR technique provides more specific and efficient amplification from low target copy numbers (29).

In the current study HPV detection was confirmed in 21 out of the 31 cases (68\%) examined with a cytological and/or histological diagnosis of HPV and/or CIN I. In ten cases HPV DNA was not detected, probably due to the presence of other type of HPV than 11, 16, 18 and 33, or to low viral copy number. This rate of detection is in accordance with previous studies $(30,31)$ detecting HPV DNA in $64 \%-75 \%$ of CIN I with cytological evidence of HPV infection, pointing to the questionable value of koilocytosis as specific marker of HPV infection, suggesting that HPV analysis is needed to prevent overclassification and overtreatment. Moreover, prevalence of high-risk HPV types (55\%) found in this study has also been reported (25).

The present study emphasizes the necessity of confirmation of HPV presence in cytological specimens by a more sensitive and specific molecular technique such as the PCR. The persistance or progression to high grade lesions in patients with mild cytological abnormalities can be predicted by molecular detection of HPV in some cases, particularly when combined with cytological analysis. However, the magnitude of this prediction is dependent on the population of patients studied and the clinical role of this approach therefore remains to be defined.

We intend to extend this pilot study and continue long-term follow-up to evaluate whether this additional test can assist in predicting which women are at greater risk of eventually developing cervical cancer.

\section{References}

1. zur Hausen $\mathrm{H}$ and de Villiers EM: Human papillomaviruses. Annu Rev Microbiol 48: 427-447, 1994.

2. Vousden KH: Viruses and human cancer. Br Med Bull 50: 560-581, 1994.

3. Lowy DR, Kirnbauer R and Schiller JT: Genital human papillomavirus infection. Proc Natl Acad Sci USA 91: 2436-2440, 1994.

4. Olsen AO, Gjoen K, Sauer T, Orstavik I, Naess O, Kierulf K, Sponland $G$ and Magnus P: Human papillomavirus and cervical intraepithelial neoplasia grade II-III: population-based casecontrol study. Int J Cancer 61: 312-315, 1995.

5. Lorincz AT, Reid R, Jenson AB, Greenberg MD, Lancaster W and Kurman RJ: Human papillomavirus infection of the cervix: relative risk associations of 15 common anogenital types. Obstet Gynaecol 79: 328-337, 1993.

6. Schiffman MH, Bauer HM, Hoover RN, Glass AG, Cadell DM, Rush BB, Scott DR, Sherman ME, Kurman RJ, Wacholder S, Stanton CK and Manos MM: Epidemiological evidence that human papillomavirus infection causes most cervical intraepithelial neoplasia. J Natl Cancer Inst 85: 958-964, 1993. 
7. Melkert PW, Hopman E, van den Bryle AJ, Risse EK, van Diest PJ, Bleker OP, Helmerhorst T, Schipper ME, Meijer CJ and Walboomers JM: Prevalence of HPV in cytomorphologically normal cervical smears, as determined by the polymerase chain reaction, is age-dependent. Int J Cancer 53: 919-923, 1993.

8. Syrjanen KJ: Human papillomavirus in genital carcinogenesis. Sex Transm Dis 21: S86-89, 1994.

9. Cuzick J, Terry G, Ho L, Hollingworth T and Anderson M: Typespecific HPV DNA in abnormal smears as a predictor of high grade cervical intraepithelial neoplasia. Br J Cancer 69: 167-171, 1994.

10. National Cancer Institute Workshop. The 1988 Bethesda System for reporting cervical/vaginal diagnoses. JAMA 262: 931-934, 1989.

11. National Cancer Institute Workshop. The revised Bethesda System for reporting cervical/vaginal diagnoses: Report of the 1991 Bethesda Workshop. JAMA 267: 1892, 1992.

12. Sherman ME, Schiffman MH, Lorincz AT, Manos MM, Scott DR, Kurman RJ, Kiviat NB, Stoler M, Glass AG and Rush BB: Towards objective quality assurance in cervical cytopathology. Correlation of cytopathologic diagnoses with detection of high-risk human papillomavirus types. Am J Clin Pathol 102: 182-187, 1994.

13. Walboomers JMM, de Roda Husman AM, van den Brule AJC, Snijders PJF and Meijer CJLM: Detection of genital human papillomavirus infections: Critical review of methods and prevalence studies in relation to cervical cancer. In: Human Papillomavirus and Cervical Cancer. Stern PL and Stanley MA (eds). Oxford University Press pp41-71, 1994.

14. Mayelo V, Garaud P, Renjard L, Dianoux L, Lansac J, Lhuintre Y, Coursaget $\mathrm{P}$ and Anthonioz $\mathrm{Ph}$ : Cell abnormalities associated with human papillomavirus-induced squamous intraepithelial cervical lesions. Multivariate analysis. Am J Clin Pathol 101: 13-18, 1994.

15. Selvaggi SM: Cytologic detection of condylomas and cervical intraepithelial neoplasia of the uterine cervix with histological correlation. Cancer 58: 2076-2081, 1986.

16. Hording U, Daugaard S and Bock JE: Detection of human papillomavirus (HPV) in cervical swabs by the polymerase chain reaction: an evaluation of the sensitivity of the method in patients with HPV 16-harboring cervical lesions. Int J Gynecol Pathol 13: 139-142, 1994.

17. Hansson BG, Forslund $\mathrm{O}$, Bjerre B, Lindholm $\mathrm{K}$ and Nordenfelt $\mathrm{E}$ : Human papillomavirus types in routine cytological screening and at colposcopic examinations. Eur J Obstet Gynecol Reprod Biol 52: 49-55, 1993.

18. de Roda Husman AM, Walboomers JM, Meijer CJ, Risse EK, Shipper ME, Helmerhorst TM, Bleker OP, Delius H, van den Brule AJ and Snijders PJ: Analysis of cytomorphologically abnormal cervical scrapes for the presence of 27 mucosotropic human papillomavirus genotypes, using polymerase chain reaction. Int J Cancer 56: 802-806, 1994.

19. Veress G, Konya J, Csiky-Meszaros T, Czegledy J and Gergely L: Human papillomavirus DNA and anti-HPV secretory IgA antibodies in cytologically normal cervical specimens. J Med Virol 43: 201-207, 1994.
20. Terry G, Ho L, Szarewski A and Cuzick J: Semiautomated detection of human papillomavirus DNA of high and low oncogenic potential in cervical smears. Clin Chem 40: 1890-1892, 1994.

21. Zazove P, Reed BD, Gregoire L, Gorenflo DW, Lancaster WD, Ruffin MT 4th and Hruszczyk J: Presence of human papillomavirus infection of the uterine cervix as determined by different detection methods in a low-risk community-based population. Arch Fam Med 2: 1250-1258, 1993.

22. Schiffman MH, Bauer HM, Lorincz AT, Manos MM, Burne JC, Glass AG, Cadell DM and Howley PM: Comparison of southern blot hybridization and polymerase chain reaction methods for the detection of human papillomavirus DNA. J Clin Microbiol 29: 573-577, 1991.

23. Burgart LJ, Heller MJ, Reznicek MJ, Greiner TC, Teneyck CJ and Robinson RA: Cytomegalovirus detection in bone marrow transplant patients with idiopathic pneumonitis. Am J Clin Pathol 96: 572-576, 1991.

24. Arends MJ, Donaldson YK, Duvall E, Wyllie AH and Bird CC: HPV in full thickness cervical biopsies: high prevalence in CIN 2 and CIN 3 detected by a sensitive PCR method. J Path 165: 301-309, 1991.

25. Cox TJ, Lorincz AT, Schiffman MH, Sherman ME, Cullen A and Kurman RJ: Human papillomavirus testing by hybrid capture appears to be usefull in triaging women with a cytologic diagnosis of atypical sqamous cells of undetermined significance. Am J Obstet Gynecol 172: 946-954, 1995.

26. Koffa M, Koumantakis E, Ergazaki M, Tsatsanis C and Spandidos DA: Association of herpesvirus infection with the development of genital cancer. Int J Cancer (In press).

27. Simons AM, Mugica van Herckenrode C, Rodriguez JA, Maintland N, Anderson M, Phillips DH and Coleman DV: Demonstration of smoking-related DNA damage in cervical epithelium and correlation with human papillomavirus type 16, using exfoliated cervical cells. Br J Cancer 71: 246-249, 1995.

28. Herrington CS, Evans MF, Hallam NF, Charnock FM, Gray W and McGee JD: Human papillomavirus status in the prediction of high-grade cervical intraepithelial neoplasia in patients with persistent low-grade cervical cytological abnormalities. Br J Cancer 71: 206-209, 1995.

29. Chou Q, Russel M, Birch DE, Raymond J and Bloch W: Prevention of pre-PCR mis-priming and primer dimerization improves low-copy-number amplifications. Nucleic Acids Res 20: 1717-1721, 1992.

30. Kuehler-Obbarius C, Milde-Langosh K, Hedling-Giese G, Salfeder A, Peimann C and Loening T: Polymerase chain reactionassisted papillomavirus detection in cervicovaginal smears: stratification by clinical risk and cytology reports. Virch Arch 425: 157-163, 1994.

31. Kuehler-Obbarius C, Milde-Langosh K, Loening T and Stegner HE: Polymerase chain reaction-assisted evaluation of low and high grade squamous intraepithelial lesion cytology and reappraisal of the Bethesda system. Acta Cytol 38: 681-686, 1994. 